\title{
POTENTIALLY TOXIC ELEMENTS IN SOILS AND CONTAMINATION INDICES AT THE SERRA PELADA GOLD MINE, PARA, BRAZIL
}

\author{
ELEMENTOS POTENCIALMENTE TÓXICOS EM SOLOS E ÍNDICES DE \\ CONTAMINAÇÃO NA ÁREA DE MINERAÇÃO DE OURO DE SERRA PELADA, \\ PARÁ, BRASIL
}

\section{Renato Alves TEIXEIRA ${ }^{1}$; Edna Santos de SOUZA ${ }^{2}$; José Roberto FERREIRA ${ }^{3}$; Antonio Rodrigues FERNANDES ${ }^{4}$}

1. Graduate program in agronomy, Federal Rural University of Amazon, Vale Institute of Technology Sustainable Development, Belém, Pará, Brasil. alves.agro@gmail.com; 2. Professor Federal Rural University of Amazon campus of Capanema; 3. Center south pole, São Paulo agribusiness technology agency (Apta); 4. Federal Rural University of Amazonia, Institute of Agrarian Science, Belém, Pará, Brazil

\begin{abstract}
The large surface stacking volume of waste and tailings at the Serra Pelada gold mine, with a high content of potentially toxic elements (PTEs), has led to environmental damage in the area, which continues to this day and is yet to be measured. Total and available $\mathrm{Cu}, \mathrm{Mo}, \mathrm{Pb}$, and $\mathrm{Zn}$ and an indicator index was formulated for soil contamination in the artisanal mining area of Serra Pelada, Amazônia, Brazil. To obtain these data, six soil samples were collected surrounding the lake formed from the mining trenches and one from a forest area outside the influence of mining activities. Metal solubilization and partial extraction were conducted by aqua regia and $0.5 \mathrm{~mol} \mathrm{~L}^{-1} \mathrm{HCl}$, respectively, followed by detection using argon plasma optical emission spectrometry. All PTEs showed total contents above the quality reference values for soils in the state of Para. The available fractions of $\mathrm{Cu}, \mathrm{Pb}$, and $\mathrm{Zn}$ were higher than the concentrations expected for Para in forest soils. The total $\mathrm{Cu}$ contents were above the value of prevention defined by the National Council of Environment. In general, there was Mo enrichment (41.0) > Cu (3.5) > Pb (1.4), indicating that the areas had been contaminated by PTEs a resulting from human activity.
\end{abstract}

KEYWORDS: Serra Pelada. Gold mining. Soils. Heavy metals; contamination.

\section{INTRODUCTION}

Gold $(\mathrm{Au})$ mining constitutes one of the main sources of environmental contamination by potentially toxic elements (PTEs) (PASSARIELO et al., 2002). In these areas, the rates of generation and artificial accumulation of PTEs are higher than those observed under natural conditions. Gold mineral exploration on an artisanal scale uses rudimentary techniques, which are generally employed by workers operating under financial limitations and with little or no formal technical instruction on how to mitigate the impacts on both the environment and human health arising from this activity (SPIEGEL; VEIGA, 2010).

High PTE content and contamination in Au mining areas is a recurring problem in several countries, including Brazil. In the state of Minas Gerais, high concentrations of $\mathrm{Zn}$ and $\mathrm{Cu}$ were found in soil samples, exceeding the quality limits of reference values expected for this substrate in that area (CESAR et al., 2011). In China, high contents of $\mathrm{Pb}, \mathrm{Cu}$, and $\mathrm{Zn}$ have been found in an Au mining area (WU et al., 2011).

Serra Pelada is the first and largest open pit mine of artisanal $\mathrm{Au}$ mining in Brazil (VEIGA; HINTON, 2002). After three decades of gold mining and subsequent closure, no research has yet been conducted to define the degree of environmental contamination by metals. Research conducted in the Amazon to evaluate metal contamination in $\mathrm{Au}$ mining areas has been restricted to the Tapajós hydrographic basin and mainly focused on $\mathrm{Hg}$ (ROULET et al., 1998; SILVA et al., 2009).

The geological characteristics of the Serra Pelada gold mine have resulted in a high mineral diversity rich in PTEs. Serra Pelada is located on a bend of metamorphic rocks at a low river level, consisting of a conglomerate of sandstone and siltstone (MORONI et al., 2001). There is a diversity of minerals, including amorphous carbon, quartz, sericite, kaolinite, hematite, goethite, manganese oxides, tourmaline traits, hematite, carbonate, chlorite, and magnetite. Furthermore, there remain primary sulfides such as pyrite, chalcopyrite, arsenopyrite, covellite, bornite, and galena as well as nickel sulfides and nickel-cobaltcopper (TALLARICO et al., 2000).

After the ceasing of gold mining activities at Serra Pelada, a village was constructed where the inhabitants developed agriculture such as horticultural crops that are marketed and supply the local market (VEIGA et al., 2006). They have also 
cultivated fruit trees in home gardens and raised cattle under a pasture system to a significant degree.

Artisanal mining activity through the deposition of tailings and waste has caused PTE contamination in the area exposed to the influence of the Serra Pelada gold mine. Knowledge of the total and available PTE concentrations in the Au mining area will enable the state to develop monitoring, control, and remediation measures to reduce the risks to public health and the ecosystem. Vegetable crop growth in the area should be analyzed, which increase plant uptake of these toxic chemical species and affect both the final consumer and the local people. The aim of this study was to evaluate the total and available concentrations of $\mathrm{Cu}, \mathrm{Mo}, \mathrm{Pb}$, and $\mathrm{Zn}$ in surface soil samples and formulate a contamination indicator index for the Au mining area of Serra Pelada.

\section{MATERIAL AND METHODS}

Serra Pelada is one of the several mineral deposits in Carajás Province in the State of Pará, in the eastern Brazilian Amazon. It lies between the coordinates 5 56'50.543"S and $4938^{\prime} 44.795^{\prime \prime} \mathrm{W}$.

Sampling areas were chosen from field observations of the current land use by residents and miners during the Au mining activity period. Thus, samples were taken from seven areas on opposite banks of the lake formed after the gold mining closure, namely: P1 - an area with no deposition of tailings and/or waste; P2 - a waste storage area and/or sterile material; P3 - an area with tailings (sediment removed from the mine not attributable to the miners' $\mathrm{Au}$ extraction activities); P4 - an area with tailings, termed Curimã by the miners, where Au was extracted; P5 - an area of sediment removed from the mine vein emptying into the lake; P6 - an area with an agroforestry system (AFS) developed approximately 7 years previously and now planted with banana, cupuaçu and cocoa; and P7 - a forest area not impacted during the artisanal Au extraction process, which constitutes the reference treatment.

Ten simple soil samples were collected at two depths: $0.0-0.2 \mathrm{~m}$ and $0.2-0.4 \mathrm{~m}$. To avoid contamination, a Dutch auger stainless steel sampler was used throughout. Samples were air dried at room temperature and sieved through a 2-mm sieve, homogenized, and stored in polypropylene bags until analysis. Samples were solubilized in a $\mathrm{H}_{2} \mathrm{SO}_{4}$ $(1+1)$ solution for the determination of $\mathrm{Si}, \mathrm{Al}, \mathrm{Fe}$, $\mathrm{Mn}$, and $\mathrm{Ti}$ oxides for further formulation of the molecular ratios $\mathrm{Ki}$ and $\mathrm{Kr}$ in the clay mineral fraction. $\mathrm{Fe}, \mathrm{Al}$, and $\mathrm{Mn}$ were determined using atomic absorption spectrometry, $\mathrm{Ti}$ using colorimetry and Si using gravimetry (EMBRAPA, 2011). The chemical attributes of the soil are provided in Table 1 and were obtained according to Embrapa (2011). K was extracted by Mehlich 1 and determined using flame photometry. $\mathrm{Ca}, \mathrm{Mg}$, and $\mathrm{Al}$ were extracted with $1 \mathrm{~mol} \mathrm{~L}^{-1} \mathrm{KCl}$ and determined via titration; $\mathrm{pH}$ in a pot soil:water ratio of 1:2.5; total organic carbon (TOC) by oxidation with $\mathrm{K}_{2} \mathrm{Cr}_{2} \mathrm{O}_{7}$, and titration by ferrous ammonium sulfate solution; and the soil organic matter (SOM) estimated as the TOC concentration multiplied by 1.72 .

Aqua regia $\left(3 \mathrm{HNO}_{3}+1 \mathrm{HCl}\right)$ was used for the total concentrations of $\mathrm{Cu}, \mathrm{Mo}, \mathrm{Pb}$, and $\mathrm{Zn}$ (MCGRATH; CUNLIFFE, 1985). The contents obtained were considered total because aqua regia extraction does not solubilize the metals present in silicate minerals. This characteristic does not interfere upon the PTE content, as values associated with the silicate fraction are not representative. For extraction of $\mathrm{Cu}, \mathrm{Mo}, \mathrm{Pb}$, and $\mathrm{Zn}$, samples weighing $0.5 \mathrm{~g}$, sieved through $100 \mathrm{mesh}$, were placed in 75$\mathrm{ml}$ digestion tubes. Then, $4 \mathrm{~mL}$ of aqua regia was added. Samples were heated for $2 \mathrm{~h}$ in a digestor block at $140^{\circ} \mathrm{C}$. After cooling, $5 \mathrm{~mL}$ of deionized water was added and they were again heated to 140 ${ }^{\circ} \mathrm{C}$ for an additional $2 \mathrm{~h}$. After cooling, volumes were completed up to $50 \mathrm{~mL}$. Extracts were filtered using a $0.45-\mu \mathrm{m}$ Nalgon filter.

The available contents of $\mathrm{Cu}, \mathrm{Mo}, \mathrm{Pb}$, and $\mathrm{Zn}$ were extracted according to Tedesco et al. (1985). A $0.5 \mathrm{~mol} \mathrm{~L}^{-1} \mathrm{HCl}$ solution was used at a ratio of 1:4, consisting of $5 \mathrm{~g}$ of soil and $20 \mathrm{~mL}$ of acid solution. The samples were moderately agitated for a period of $16 \mathrm{~h}$. Then the volume was topped to $50 \mathrm{~mL}$ and filtered.

Determination of the $\mathrm{Cu}, \mathrm{Mo}, \mathrm{Pb}$, and $\mathrm{Zn}$ PTEs was conducted using inductively coupled plasma optical emission spectrometry (ICP-OES) in a Perkin Elmer 3300 (Norwalk, USA). All sample analyses were performed in triplicate, including blanks. The analytical control for both total and available contents was completed by standard additions. Analytical curves were built as per their respective arrays of extraction, as follows: 0 to 20 $\mathrm{mg}$ for $\mathrm{Cu}$; 0 to $15 \mathrm{mg}$ for $\mathrm{Zn}$; 0 to $10 \mathrm{mg}$ for $\mathrm{Pb}$, and 0 to $10 \mathrm{mg}$ for Mo.

PTEs were found at depths of $0.0-0.2$ and $0.2-0.4 \mathrm{~m}$ in the mining area of influence of the Serra Pelada soils and were evaluated via a comparison to the quality of reference values (QRVs) of land in the State of Pará established by Fernandes et al. (2018). 
Table 1. Soil chemical attributes in the Serra Pelada mining area.

\begin{tabular}{|c|c|c|c|c|c|c|c|c|c|}
\hline $\begin{array}{l}\text { Sampling } \\
\text { points }\end{array}$ & $\mathrm{pH}$ & ${ }^{1} \mathrm{SOM}$ & Clay & $\begin{array}{l}{ }^{2} \mathrm{SiO}_{2} \\
\mathrm{~g} \mathrm{~kg}^{-1} .\end{array}$ & ${ }^{3} \mathrm{Al}_{2} \mathrm{O}_{3}$ & ${ }^{4} \mathrm{Fe}_{2} \mathrm{O}_{3}$ & $\begin{array}{l}{ }^{5} \mathrm{TiO}_{2} \\
\ldots . .\end{array}$ & ${ }^{6} \mathrm{MnO}$ & $\begin{array}{l}{ }^{7} \mathrm{CEC} \\
\mathrm{cmol}_{\mathrm{c}} \mathrm{dm}^{-3}\end{array}$ \\
\hline \multicolumn{10}{|c|}{$0.0-0,2 \mathrm{~m}$} \\
\hline P1 & 6.07 & 2.52 & 380 & 2.2 & 3.3 & 3.6 & 0.4 & 2.0 & 1.30 \\
\hline P2 & 6.50 & 10.52 & 391.5 & 17.7 & 14.4 & 12.4 & 2.4 & 0.90 & 3.60 \\
\hline P3 & 5.74 & 2.67 & 267.3 & 11.6 & 11.3 & 3.9 & 0.7 & 0.90 & 1.20 \\
\hline P4 & 7.08 & 1.95 & 256 & 1.0 & 2.0 & 8.8 & 2.4 & 0.8 & 1.30 \\
\hline P5 & 6.86 & 1.33 & 103 & 1.2 & 3.7 & 26.0 & 6.6 & 1.4 & 1.40 \\
\hline P6 & 5.55 & 11.30 & 380 & 27.9 & 22.1 & 10.6 & 2.0 & 0.6 & 5.50 \\
\hline P7 & 4.16 & 12.92 & 464 & 20.7 & 17.1 & 8.8 & 1.6 & 0.04 & 2.50 \\
\hline \multicolumn{10}{|c|}{$0.2-0.4 \mathrm{~m}$} \\
\hline P1 & 6.75 & 0.88 & 330 & 1.7 & 2.5 & 2.7 & 0.5 & 4.1 & 1.10 \\
\hline P2 & 6.20 & 2.76 & 370 & 18.1 & 13.3 & 9.7 & 3.5 & 0.5 & 6.20 \\
\hline P3 & 5.92 & 3.13 & 246 & 10.4 & 9.2 & 4.1 & 0.5 & 0.8 & 1.18 \\
\hline P4 & 6.92 & 1.87 & 228 & 1.0 & 3.2 & 8.8 & 3.1 & 0.8 & 1.30 \\
\hline P5 & 6.63 & 1.99 & 98.4 & 2.7 & 4.6 & 16.3 & 5.3 & 0.8 & 1.30 \\
\hline P6 & 6.05 & 2.55 & 301.3 & 30.8 & 22.5 & 8.9 & 2.3 & 0.3 & 5.20 \\
\hline P7 & 4.25 & 6.29 & 458.2 & 16.2 & 14.7 & 7.3 & 1.3 & 0.04 & 1.82 \\
\hline
\end{tabular}

${ }^{1}$ Soil Organic Matter ${ }^{2}$ Silicium oxide ${ }^{3}$ Aluminium oxide ${ }^{4}$ Iron oxide ${ }^{5}$ Titanium oxide ${ }^{6}{ }^{6}$ Manganese Oxide ${ }^{7}$ Cation exchange capacity. P1: Lake margins; P2: Lake margins; P3: Tailings pile; P4: Waste pile; P5: Mine sediment; P6: Agroforestry system; P7: Riparian forest.

The enhancement factor (EF), contamination factor $(\mathrm{CF})$ and pollutant load index (PLI) were determined to assess the degree of PTE contamination in the studied area. All these indices were discussed according to the QRVs for $\mathrm{Fe}$ established by Fernandes et al. (2018).for the state of Para. Fe was used as the reference element for the geochemistry standards because it has a geochemical behavior similar to many PTEs and because of its conservative properties (BHUIYAN et al., 2009). The EF was obtained for each of the four PTEs selected for this research using equation 1 as follows:

$$
\mathrm{EF}=\frac{\mathrm{X} 1 / \mathrm{Y} 1}{\mathrm{X} 2 / \mathrm{Y} 2} \quad \text { equation } 1
$$

where $\mathrm{X} 1$ is the concentration in $\mathrm{mg} \mathrm{kg}^{-1}$ of the PTE solubilized in hot aqua regia and $\mathrm{Y} 1$ is the concentration in $\mathrm{m} \mathrm{kg}^{-1}$ of $\mathrm{Fe}$ in the same extract. $\mathrm{X} 2$ is the QRV for Fe in Para soils and Y2 the Fe concentration in the considered soil sample. An EF $<1$ indicates no enrichment, and $\mathrm{EF}>1<3$ is low enrichment, an $\mathrm{EF}>3<5$ is moderate enrichment, an $\mathrm{EF}>5<10$ is moderately severe enrichment, an $\mathrm{EF} 10<25$ is severe enrichment, an EF $>25<50$ is very serious enrichment, and an $\mathrm{EF}>50$ is extremely serious enrichment (SAKAN et al., 2009).

$\mathrm{CF}$ is the ratio obtained between the concentration in $\mathrm{mg} \mathrm{kg}^{-1}$ of PTEs determined by the attack aqua regia and the extracting reference value obtained by applying EPA 3051 using equation 3 as follows:

$$
\mathrm{CF}=\frac{[] \mathrm{PTE}}{[] \mathrm{QRV}} \quad \text { equation } 2
$$

The CF was interpreted according to the formula proposed by Muller (1969) where CF $<1$ is without contamination; a $\mathrm{CF}>1<3$ is moderate contamination; a $\mathrm{CF}>3<6$ is considerable contamination, and a $\mathrm{CF}>6$ is highly contaminated.

The pollutant load index (PLI) of each sampling point was obtained from the $n$-th root of the sum of the CF of all metals using equation 3 as follows:

$\mathrm{PLI}=\sqrt[\mathrm{n}]{\mathrm{CF} 1+\mathrm{CF} 2+\mathrm{CF} 3 \ldots \mathrm{CFn}}$ equation 3

This ratio offers a comparative means for assessing contamination by heavy metals, in which PLI $<1$ denotes the non-existence of PTE contamination and PLI $>1$ denotes heavy metal pollution (RASHED, 2010). A descriptive statistical analysis of the total and available PTE contents was conducted together with a Pearson correlation analysis between the total content of PTEs and iron, manganese, titanium, and aluminum oxides; organic matter (OM); and clay. The total and available content of PTEs; Fe, Mn, Al, Ti and Si oxides; and the SOM content were subjected to principal component analysis (PCA).

\section{RESULTS}

The total $\mathrm{Zn}, \mathrm{Cu}, \mathrm{Pb}$ and $\mathrm{Mo}$ contents at the Serra Pelada gold mine and surrounding area were greater than those established for the respective reference values of soil quality $(\mathrm{QRV})$, i.e. higher than those found in the Para soil in its natural state (Table 2). An exception to these results were the $\mathrm{Pb}$ 
concentrations for soil layers sampled in a riparian forest (P7) and in the subsurface layer in an area with an agroforestry system (P6). It was observed that the reference area had been well-selected as lower concentrations for all metals were present, suggesting they were free of anthropogenic contamination.

Table 2. Total PTE concentrations in the Au mining area of Serra Pelada.

\begin{tabular}{|c|c|c|c|c|}
\hline \multirow[t]{2}{*}{ Collection points } & $\mathrm{Zn}$ & $\mathrm{Cu}$ & $\mathrm{Pb}$ & Mo \\
\hline & \multicolumn{4}{|c|}{ 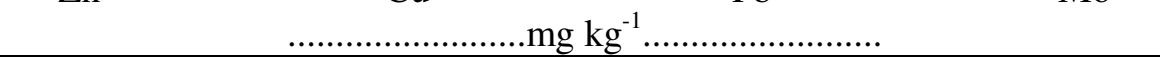 } \\
\hline & \multicolumn{4}{|c|}{$0.0-0.2 \mathrm{~m}$} \\
\hline P1 & $30.1 \pm 1.5$ & $91.3 \pm 7.3$ & $29.4 \pm 1.6$ & $8.1 \pm 0.06$ \\
\hline P2 & $78.4 \pm 3.8$ & $119.5 \pm$ & $20.1 \pm 0.8$ & $8.7 \pm 0.41$ \\
\hline P3 & $27.8 \pm 1.8$ & $60.8 \pm 3.0$ & $35.6 \pm 1.7$ & $8.3 \pm 0.02$ \\
\hline P4 & $56.0 \pm 0.4$ & $72.4 \pm 2.8$ & $18.3 \pm 1.4$ & $8.5 \pm 0.02$ \\
\hline P5 & $80.5 \pm 6.9$ & $78.9 \pm 8.3$ & $26.6 \pm 2.1$ & $8.2 \pm 0.2$ \\
\hline P6 & $37.7 \pm 9.8$ & $180.1 \pm 5.6$ & $8.8 \pm 1.1$ & $8.0 \pm 0.1$ \\
\hline P7 & $14.7 \pm 0.3$ & $24.4 \pm 0.4$ & $3.9 \pm 0.5$ & $7.9 \pm 0.02$ \\
\hline & \multicolumn{4}{|c|}{$0.2-0.4 \mathrm{~m}$} \\
\hline P1 & $19.3 \pm 2.1$ & $73.1 \pm 4.3$ & $30.1 \pm 1.5$ & $7.8 \pm 0.02$ \\
\hline P2 & $75.9 \pm 3.8$ & $181.3 \pm 7.4$ & $24.9 \pm 2.4$ & $8.5 \pm 0.02$ \\
\hline P3 & $28.9 \pm 2.0$ & $63.9 \pm 1.8$ & $40.4 \pm 5.9$ & $8.2 \pm 0.1$ \\
\hline P4 & $46.0 \pm 6.5$ & $54.5 \pm 6.3$ & $15.0 \pm 1.1$ & $8.6 \pm 0.1$ \\
\hline P5 & $82.1 \pm 4.8$ & $89.2 \pm 7.7$ & $27.19 \pm 1.6$ & $7.8 \pm 0.1$ \\
\hline P6 & $35.6 \pm 6.6$ & $156.9 \pm 2.9$ & $3.72 \pm 0.7$ & $8.2 \pm 0.2$ \\
\hline P7 & $12.3 \pm 0.8$ & $18.9 \pm 0.5$ & $3.2 \pm 0.6$ & $8.7 \pm 0.7$ \\
\hline QRV & 7.2 & 9.9 & 4.0 & 0.05 \\
\hline PV & 300 & 60 & 72 & 30 \\
\hline IV & 450 & 200 & 180 & 50 \\
\hline
\end{tabular}

P1: Lake margins; P2: Lake margins; P3: Tailings pile; P4: Waste pile; P5: Mine sediment; P6: Agroforestry system; P7: Riparian forest. QRV: Quality reference values (FERNANDES et al. 2018). PV: Prevention value (CONAMA, 2009). Investigation value (CONAMA, 2009).

$\mathrm{Cu}$ was the only metal with its contents exceeding the prevention value (PV) established by Conama (2009). Pb, Zn, and Mo showed no concentrations above the PV Conama (2009) but were higher than the QRVs for the state of Para. Zn contents were up to 11.3 times higher than the QRVs, $\mathrm{Pb}$ up to 7.5 times, and Mo up to 175 times. It should also be considered that $\mathrm{Cu}$ and $\mathrm{Pb}$ are extracted more efficiently using the EPA method 3051 than with hot aqua regia, which, enhanced these comparisons with the PV as established by the EPA.

In the surface layer the available $\mathrm{Zn}$ contents at a depth of $0-0.2 \mathrm{~m}$ varied between 1.7 and $27.5 \mathrm{mg} \mathrm{kg}^{-1} \mathrm{Zn}$ (Table 3). At 0.2-0.4 m, the $\mathrm{Zn}$ concentrations varied between 0.5 and $12.7 \mathrm{mg} \mathrm{kg}^{-1}$ $\mathrm{Zn}$. Even values for soil extraction in a cold $0.5 \mathrm{~mol}$ $\mathrm{L}^{-1} \mathrm{HCl}$ solution were above those established as QRVs of at least one of the layers studied at P2, P5, and P6 (Table 3). At the soil surface, the available $\mathrm{Cu}$ was found to be in a range from 2.9 to $55.4 \mathrm{mg}$ $\mathrm{kg}^{-1}$, while in the .2-0.4-m layer, from 2.5 to 48.5 $\mathrm{mg} \mathrm{kg}^{-1} \mathrm{Cu}$ was found (Table 3). At P2, P4, P5 and $\mathrm{P} 6$, in at least one of the depths, the available $\mathrm{Cu}$ was found in concentrations greater than those expected for the QRVs.

The available $\mathrm{Pb}$ varied in a range from 0.9 to $13.9 \mathrm{mg} \mathrm{kg}^{-1}$ at the soil surface, whereas in deeper layers it decreased, ranging from 0.5 to $9.7 \mathrm{mg} \mathrm{kg}^{-1}$ $\mathrm{Pb}$ (Table 2). In P2, P4, P5, and P6, available $\mathrm{Pb}$ concentrations were greater than the QRVs in at least one of the layers (Table 2). The available Mo concentrations were higher than the QRVs in all areas evaluated, and showed a similar range for both depths, 0.9 to $1.6 \mathrm{mg} \mathrm{kg}^{-1}(0-0.2 \mathrm{~m})$ and 0.8 to 1.5 (0.2-0.4 m) (Table 3).

According to Table 4, the average $\mathrm{CF}$ presented the following sequence at the 0 to $0.2 \mathrm{~m}$ depth: $\mathrm{Mo} \mathrm{(41.0),} \mathrm{Cu}$ (3.5), $\mathrm{Pb}(1.4)$ and $\mathrm{Zn}(0.9)$. At a depth of 0.2 to $0.4 \mathrm{~m}$, the same behavior of metals was found, $\mathrm{Mo} \mathrm{(44.0),} \mathrm{Cu}$ (3.8), $\mathrm{Pb}$ (1.6), and $\mathrm{Zn}$ (0.8), with slightly higher values except for $\mathrm{Zn}$. Given this situation, it was possible to classify the study area as one with very serious contamination for $\mathrm{Mo}$, moderate for $\mathrm{Cu}$, and low for both $\mathrm{Pb}$ and $\mathrm{Zn}$ as no enrichments were observed for these metals (SAKAN et al., 2009). 
Table 3. Available PTE concentrations in the Serra Pelada gold mining area.

\begin{tabular}{ccccc}
\hline Collection points & $\mathrm{Zn}$ & $\mathrm{Cu}$ & $\mathrm{Pb}$ & Mo \\
& \multicolumn{4}{c}{$\ldots \ldots \ldots \ldots \ldots \ldots \mathrm{mg} \mathrm{kg}^{-1} \ldots \ldots \ldots \ldots .}$. \\
P1 & 1.4 & $0.0-0.2 \mathrm{~m}$ & 1.1 & \\
P2 & 27.5 & 2.9 & 13.9 & 1.6 \\
P3 & 2.8 & 55.3 & 0.9 & 1.2 \\
P4 & 9.4 & 11.5 & 3.1 & 1.2 \\
P5 & 12.5 & 13.2 & 10.3 & 0.9 \\
P6 & 13.0 & 47.7 & 5.4 & 1.4 \\
P7 & 1.7 & 3.4 & 2.4 & 1.5 \\
P1 & 1.9 & $0.2-0.4 \mathrm{~m}$ & 0.5 & 1.5 \\
P2 & 12.7 & 2.5 & 9.7 & 1.2 \\
P3 & 1.9 & 48.5 & 0.8 & 1.5 \\
P4 & 12.9 & 3.4 & 4.9 & 0.9 \\
P5 & 9.3 & 24.4 & 4.1 & 0.8 \\
P6 & 9.6 & 14.5 & 5.7 & 1.5 \\
P7 & 0.5 & 28.7 & 2.0 & 1.5 \\
\hline
\end{tabular}

P1: Lake margins; P2: Lake margins; P3: Tailings pile; P4: Waste pile; P5: Mine sediment; P6: Agroforestry system; P7: Riparian forest.

Table 4. EF, CF, and PLI for PTEs in the Serra Pelada soils.

\begin{tabular}{cccccccccc}
\hline \multirow{2}{*}{ Collection points } & \multicolumn{3}{c}{ Enrichment Factor } & \multirow{2}{*}{ PLI } & \multicolumn{3}{c}{ Contamination Factor } \\
& $\mathrm{Zn}$ & $\mathrm{Cu}$ & $\mathrm{Pb}$ & $\mathrm{Mo}$ & & $\mathrm{Zn}$ & $\mathrm{Cu}$ & $\mathrm{Pb}$ & $\mathrm{Mo}$ \\
\hline & & & \multicolumn{2}{c}{$0.0-0.2 \mathrm{~m}$} & & & & & \\
\hline P1 & 2.5 & 15.0 & 7.4 & 162.2 & 14.6 & 0.9 & 5.6 & 2.7 & 60.6 \\
P2 & 6.5 & 19.6 & 5.0 & 175.5 & 18.3 & 1.1 & 3.3 & 0.9 & 29.8 \\
P3 & 2.3 & 10.0 & 8.9 & 165.5 & 13.6 & 0.9 & 3.8 & 3.3 & 62.3 \\
P4 & 4.7 & 11.9 & 4.6 & 170.8 & 14.4 & 1.1 & 2.9 & 1.1 & 41.1 \\
P5 & 6.7 & 12.9 & 6.7 & 164.1 & 17.5 & 1.3 & 2.5 & 1.3 & 31.3 \\
P6 & 3.1 & 29.5 & 2.2 & 160.4 & 13.4 & 0.6 & 5.9 & 0.4 & 32.3 \\
P7 & 1.2 & 4.0 & 1.0 & 159.9 & 5.3 & 0.2 & 0.7 & 0.2 & 29.4 \\
Mean & 3.9 & 14.7 & 5.1 & 165.5 & 13.9 & 0.9 & 3.5 & 1.4 & 41.0 \\
\hline & & & & $0,2-0,4 m$ & & & & & \\
P1 & 1.6 & 12.0 & 7.5 & 157.0 & 12.3 & 0.9 & 6.4 & 4.0 & 83.7 \\
P2 & 6.3 & 29.7 & 6.2 & 169.4 & 21.1 & 1.0 & 4.5 & 0.9 & 25.7 \\
P3 & 2.4 & 10.5 & 10.1 & 164.7 & 14.3 & 0.8 & 3.6 & 3.5 & 56.3 \\
P4 & 3.8 & 8.9 & 3.7 & 172.6 & 12.2 & 1.0 & 2.4 & 1.0 & 45.6 \\
P5 & 6.8 & 14.6 & 6.8 & 155.5 & 18.0 & 1.2 & 2.5 & 1.2 & 26.3 \\
P6 & 3.0 & 25.7 & 0.9 & 164.0 & 10.4 & 0.7 & 6.4 & 0.2 & 41.1 \\
P7 & 1.0 & 3.1 & 0.8 & 173.0 & 4.6 & 0.2 & 0.6 & 0.1 & 31.8 \\
Mean & 3.6 & 14.9 & 5.2 & 165.2 & 13.3 & 0.8 & 3.8 & 1.6 & 44.4 \\
\hline
\end{tabular}

P1: Lake margins; P2: Lake margins; P3: Tailings pile; P4: Waste pile; P5: Mine sediment; P6: Agroforestry system; P7: Riparian forest.

The EF had the same sequence observed for the $\mathrm{CF}$, at the surface $(0-0.2 \mathrm{~m})$ and at the deeper soil layer $(0.2-0.4 \mathrm{~m})$, the highest value being that of Mo (165.5) followed by $\mathrm{Cu}$ (14.7), $\mathrm{Pb}(5.1)$, and $\mathrm{Zn}$ (3.9) (Table 4). These results indicate that the area is heavily contaminated by $\mathrm{Mo}$ and $\mathrm{Cu}$
(MULLER, 1969), and that there is some contamination by $\mathrm{Pb}$ and $\mathrm{Zn}$ (Table 4).

A pollutant loading index (PLI) greater than 1 was obtained for all the studied areas, indicating the occurrence of a group of pollutants (RASHED, 2010), even when considering the P7 area, the 
reference site for the study area. These data, like a tracer, denote the influence of local anthropogenic activity at P7 (Table 4).
There were significant negative correlations between total $\mathrm{Pb}$ and $\mathrm{SiO}_{2}(\mathrm{r}=-0.6 \mathrm{p}<0.05), \mathrm{Al}_{2} \mathrm{O}_{3}$ $(\mathrm{r}=-0.6 \mathrm{p}<0.05) \mathrm{MnO}(\mathrm{r}=-0.5 \mathrm{p}<0.05)$, and SOM $(r=-0.5 p<0.05)($ Table 5).

Table 5. Pearson correlation matrix between PTEs and soil attributes in the Serra Pelada SOM.

\begin{tabular}{ccccccccccc} 
& $\mathrm{Zn}$ & $\mathrm{Cu}$ & $\mathrm{Pb}$ & $\mathrm{Mo}$ & $\mathrm{SiO}_{2}$ & $\mathrm{Al}_{2} \mathrm{O}_{3}$ & $\mathrm{Fe}_{2} \mathrm{O}_{3}$ & $\mathrm{TiO}_{2}$ & $\mathrm{MnO}$ & $\mathrm{Clay}$ \\
\hline $\mathrm{Cu}$ & 0.4 & & & & & & & & & \\
$\mathrm{~Pb}$ & 0.2 & 0.1 & & & & & & & & \\
$\mathrm{Mo}$ & 0.2 & 0.1 & 0.2 & & & & & & \\
$\mathrm{SiO}_{2}$ & -0.2 & 0.5 & $-0.6^{*}$ & 0.1 & & & & & \\
$\mathrm{Al}_{2} \mathrm{O}_{3}$ & -0.2 & 0.4 & $-0.6^{*}$ & 0.1 & $0.9^{* *}$ & & & & \\
$\mathrm{Fe}_{2} \mathrm{O}_{3}$ & $0.7^{* *}$ & 0.2 & -0.1 & -0.0 & -0.1 & -0.1 & & & \\
$\mathrm{TiO}_{2}$ & $0.8^{* *}$ & 0.2 & -0.0 & -0.0 & -0.2 & -0.2 & $0.9^{* *}$ & & & \\
$\mathrm{MnO}$ & -0.1 & -0.0 & $-0.5^{*}$ & -0.4 & $-0.6^{*}$ & -0.2 & -0.9 & & & \\
$\mathrm{Clay}$ & $-0.6^{*}$ & 0.0 & -0.5 & 0.2 & $0.6^{*}$ & $0.6^{*}$ & $-0.5^{*}$ & $-0.7^{*}$ & -0.2 & \\
${ }^{1} \mathrm{SOM}$ & -0.2 & 0.1 & $-0.5^{*}$ & 0.1 & $0.6^{*}$ & $0.7^{* *}$ & 0.0 & 0.2 & 0.4 & $0.7^{* *}$ \\
\hline
\end{tabular}

* Significant correlation $\mathrm{p}<0.05 * *$ Significant correlation $\mathrm{p}<0.01$

There were significant positive correlations between $\mathrm{Zn}$ and $\mathrm{Fe}_{2} \mathrm{O}_{3}(\mathrm{r}=0.7, \mathrm{p}<0.01)$ and $\mathrm{TiO}_{2}$ $(\mathrm{r}=0.82, \mathrm{p}<0.05)$, between $\mathrm{SiO}_{2}$ and $\mathrm{Al}_{2} \mathrm{O}_{3}(\mathrm{r}=0.9$, $\mathrm{p}<0.01)$; and between clay $(\mathrm{r}=0.6, \mathrm{p}<0.05)$ and SOM $(r=0.6, p<0.05)$ (Table 5).

The $\mathrm{Al}_{2} \mathrm{O}_{3}$ content positively correlated with the clay $(\mathrm{r}=0.6, \mathrm{p}<0.05)$ and $\mathrm{SOM}(\mathrm{r}=0.7, \mathrm{p}<$ $0.01) . \mathrm{Fe}_{2} \mathrm{O}_{3}$ content positively correlated with $\mathrm{TiO}_{2}$ $(\mathrm{r}=0.94, \mathrm{p}<0.01)$, though negatively with clay $(\mathrm{r}=$ $-0.5, \mathrm{p}<0.05)($ Table 5).
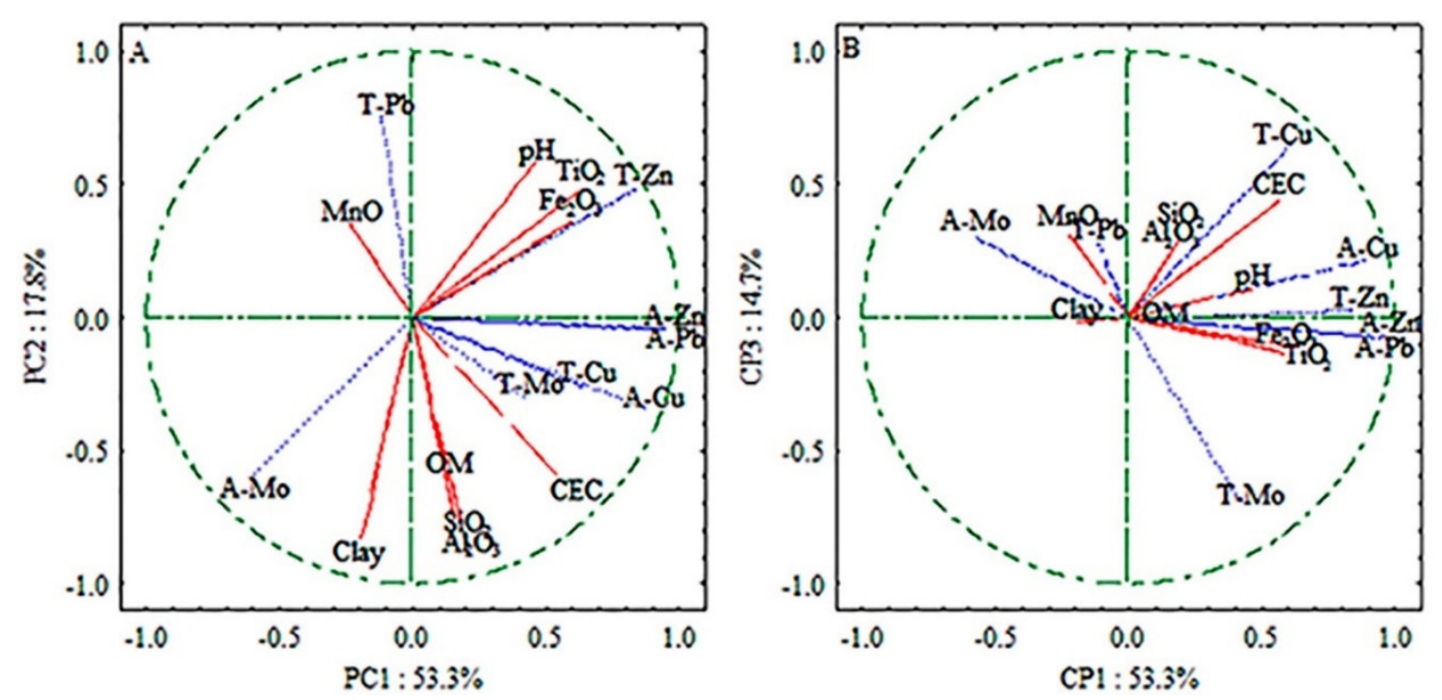

Figure 1. Multivariate analysis of soil attributes of the Serra Pelada gold mine area.

The first component (PC1) explained 53.3\% of the results, the second (PC2) $17.8 \%$ (Figure $1 \mathrm{~A}$ ), and the third (PC3) $14.7 \%$ (Figure 1B).

The available $\mathrm{Zn}, \mathrm{Cu}$, and $\mathrm{Pb}$ and total $\mathrm{Zn}$, $\mathrm{Fe}$, and $\mathrm{Ti}$ were associated by $\mathrm{PC} 1$, whereas the available Mo negatively correlated with this component. Total $\mathrm{Pb}$ and $\mathrm{pH}$ were positively
The set of data for the PCA was selected combining the average physical and chemical data of the two layers, as there were no significant differences in the PTE concentrations between the layers. In this approach, three principal components (PCs) were selected, which properly described the correlations between the total and available PTEs and the physical and chemical attributes of the soil, explaining $85.8 \%$ of the total variation (Figure 1).

associated with $\mathrm{PC} 2$ and negatively with $\mathrm{Si}, \mathrm{Al}$ oxides, SOM, clay, and cation-exchange capacity (CEC). $\mathrm{Cu}$ total content positively correlated with PC3 and negatively with available Mo. 


\section{DISCUSSION}

The total PTE contents (Table 2) were in excess of the QRV for soils in the state of Para (ALLEONI et al., 2011), and are associated with the geological characteristics of the region and the high mineral diversity (TALLARICO et al., 2000). The Serra Pelada mining area is on a hydrothermal stem where a predominance of volcanic rocks occurs, influencing mineralization(ALMADA et al., 1999), and which are recognized natural sources of PTEs (NAGAJYOTI et al., 2010).

$\mathrm{Cu}$ contents in excess of the VP (Table 2) can be attributed to the occurrence of Carrollite, a sulfur mineral, observed in this area (TALLARICO, 2000). $\mathrm{Cu}$ contents in in soils above the values of the VP are a limiting factor for that particular element in the area and are able to negatively influence their functions (CONAMA, 2009). However, this may be indicative of changes in the natural quality of the soil, caused by artisanal $\mathrm{Au}$ mining, which expose a surface material rich in $\mathrm{Cu}$. The enrichment of $\mathrm{Cu}$, particularly in the mining vein margins, is probably because of increased $\mathrm{Cu}$ mineralization on the surface as result of the process of $\mathrm{Au}$ prospection as noted by Kesharvazi et al. (2012) in Iran in an Au mining area. In a chromite mining area in Indonesia, an EF ranging from 0 to 3.37 was found, which is in the same range of those found at the two different soil depths at Serra Pelada, indicating $\mathrm{Cu}$ contamination (KRISHNA et al., 2013).

As noted, high $\mathrm{Cu}$ contents in $\mathrm{Au}$ mining areas in Serra Pelada are recurrent problems. In an artisanal gold mining area in Descorberto, Minas Gerais, Brazil, concentrations of $62.7 \mathrm{mg} \mathrm{kg}^{-1} \mathrm{Cu}$ were found (CESAR et al., 2011). In four artisanal mines in Migori, Southwestern Kenya, where soil samples were collected near sediment ponds, concentrations up to $487 \mathrm{mg} \mathrm{kg}^{-1} \mathrm{Cu}$ were found (ODUMO et al., 2011).

The presence of galena $(\mathrm{PbS})$, a rich sulfurous $\mathrm{Pb}$ mineral occurring as an additional mineral in the Serra Pelada rocks (TALLARICO et al., 2000), may explain the higher content of this element in the soil samples when compared to the QRV in the state of Para (Table 2). This statement can be supported by data obtained from samples of a mining area soil and galena metallurgy in Adrianopolis, Parana, Brazil, where concentrations as high as $25.930 \mathrm{mg} \mathrm{kg}^{-1} \mathrm{~Pb}$ were obtained (BARROS et al., 2011).

The highest total $\mathrm{Pb}$ concentrations in samples collected at the surface $(0-0.2 \mathrm{~m})$, were found in the margins, where the sediment transported from mine and tailings settles, demonstrating the influence of $\mathrm{Au}$ mining activities. At an $\mathrm{Au}$ mining area in Egypt, higher $\mathrm{Pb}$ concentrations were also found in areas closer to the mine, up to $29 \mathrm{mg} \mathrm{kg}^{-1}$, whereas at remote sites, contents were approximately $7 \mathrm{mg} \quad \mathrm{kg}^{-1} \mathrm{~Pb}$ (RASHED, 2010). At an Au mining area in Bolivia, an average content of $16.5 \mathrm{mg} \mathrm{kg}^{-1} \mathrm{~Pb}$ was found; these contents were assigned to the type of source material (FAZ et al., 2014).

The Mo content in Serra Pelada was up to 173 times higher than the QRV established for soils in the state of Para, which is $0.05 \mathrm{mg} \mathrm{kg}^{-1} \mathrm{Mo}$, attributable to the richness of the source material in this element. In soils rich in metals, the Mo average concentration has reached $100 \mathrm{mg} \mathrm{kg}^{-1}$ Mo (HE et al., 2005), higher than those values found in this study. At an Au mining area in the city of Adola, Southeastern Ethiopia, a Mo content of $8.0 \mathrm{mg} \mathrm{kg}^{-1}$ was found (GETANEH; ALEMAYEHU, 2006), similar to those observed in this study. A Similar concentration of $6.9 \mathrm{mg} \mathrm{kg}^{-1}$ Mo was found at a chromite exploration area in India (KRISHNA et al., 2013). It should be noted that the highest levels of Mo were observed in the sampling areas near the mine. In Egypt, higher contents were also found closer to mining areas, where levels of $60 \mathrm{mg} \mathrm{kg}^{-1}$ Mo were observed, while in remote areas these levels decreased to $9 \mathrm{mg} \mathrm{kg}^{-1}$ Mo (RASHED, 2010).

On average, the contents of available $\mathrm{Cu}$, $\mathrm{Pb}$, and $\mathrm{Zn}$ are higher than those observed in reference soils for the native vegetation area in the state of Para, corresponding to 1.19, 0.23, and 1.04 $\mathrm{mg} \mathrm{kg}{ }^{-1}$, respectively (BIRANNI et al., 2015). Overall, tropical soils, such as those found in the state of Para, usually have low available PTE content because of the formation of sedimentary rocks and the high degree of weathering in these soils (SOUZA et al., 2015). The intense tropical weathering observed in the high content and decomposition of organic matter in soils, as well as the prevalence of clay minerals of low activity and $\mathrm{Fe}$ and $\mathrm{Al}$ oxides, reduces PTE adsorption, enhancing cation leaching (RIEUWERTS, 2007).

Serra Pelada, underlain by a bend in the metamorphic rocks with a low fluvial activity, is composed of a sandstone and siltstone conglomerate (MORONI et al., 2001) and a wide variety of primary minerals and oxides (TALLARICO et al., 2000) that presents higher content than other regions in the state. In addition, after the tailings and waste deposition on the soil surface, elements are solubilized, thereby enhancing the available PTE content in the region. 
Potentially toxic...

Negative correlations $(\mathrm{p}<0.05)$ between $b$ content and $\mathrm{SiO}_{2}$ (Table 5) are a result of the reduction in $\mathrm{Pb}$ sulfate concentration where there are high contents of silicates in the soil. In Serra Pelada soils, the main $\mathrm{Pb}$ species is $\mathrm{PbS}$ (galena) which occurs as an accessory mineral (TALLARICO et al., 2000). The negative correlation $(\mathrm{p}<0.05)$ between $\mathrm{Pb}$ and SOM may be related to low $\mathrm{OM}$ contents in the soil and also because $\mathrm{Pb}$ correlates more strongly with $\mathrm{OM}$ in its available fraction (ANJU; BANERJEE, 2011).

The positive correlation $(\mathrm{p}<0.05)$ observed between $\mathrm{Zn}$ and both $\mathrm{Fe}_{2} \mathrm{O}_{3}$ and $\mathrm{TiO}_{2}$ (Table 5) is associated with adsorption geochemical support (in this case $\mathrm{Fe}$ and $\mathrm{Ti}$ oxide), leading to a decrease in the mobility of this element in the soil (CESAR et al., 2011). This allows $\mathrm{Zn}$ to remain in the system, even under intense weathering conditions (ANJU; BANERJEE, 2011). Cesar et al. (2011), studying areas affected by the mining of $\mathrm{Au}$ in Minas Gerais, also found a high affinity of $\mathrm{Zn}$ with $\mathrm{Fe}$ and $\mathrm{Al}$ oxides. In all situations, the adsorption increases with increased soil pH (FERREIRA et al., 1995).

There was an association between total $\mathrm{Pb}$ and $\mathrm{Mn}$ oxides (Figure 1a), indicating that $\mathrm{Pb}$ is precipitated as part of the structure or adsorbed on the surface of these oxides. $\mathrm{Pb}$ has a strong affinity with Mn oxides, which is the main site of adsorption of the element in the soil (WANG et al., 2015). This process is favored by deprotonation of the hydroxyl at the margins of the oxides, which encourages specific $\mathrm{Pb}$ precipitation or adsorption on the internal cavities and between the layers of minerals such as birnessite, a type of Mn oxide (LEE et al., 2013).

The absence of a correlation between the contents of available PTEs and SOM (Figure 1) is an unusual situation, which may be because of low OM contents in the soil and mining waste (Table 1). Furthermore, the $\mathrm{OM}$ mineralization rate increases in tropical soils, also contributing to the lack of organic acids, decreasing the active sites for PTE complexation (KABATA-PENDIAS, 2011). Other authors have reported the same phenomenon for $\mathrm{Pb}$ and $\mathrm{Zn}$ in a mining area in India (ANJU; BANERJEE, 2011) resulting from the low OM content in the soil.

The significant positive correlation between the available $\mathrm{Cu}, \mathrm{Zn}$, and $\mathrm{Pb}$ and $\mathrm{CEC}$ (Figures 1a and $1 \mathrm{~b}$ ) may be explained by CEC being among the main attributes of the soil acting on the solubility, mobility, and availability of PTEs (RIEWERTS, 2007). In soils of $\mathrm{pH}$-dependent charges, prevalent
TEIXEIRA, R. A. et al.

in tropical regions at high CEC, mobility is reduced, while CEC decreases with low retention (RIEWERTS, 2007; SOUZA et al., 2015).

The correlation between the Fe oxides, $\mathrm{Ti}$, and $\mathrm{Zn}$ may be related to the association between $\mathrm{Ti}$ oxides with $\mathrm{Fe}$ oxides, part of the formation of minerals such as rutile and ilmenite, present in the mineralogy in the mineral province of Carajás (TALLARICO et al., 2000). Similar chemical properties between $\mathrm{Fe}^{2+}, \mathrm{Ti}^{2+}$, and $\mathrm{Zn}^{2+}$ enable solubilization and recrystallization in acids in relation to $\mathrm{pH}$ near neutrality, forming new minerals rich in Zn (RUSSEL, 1994).

The low availability of $\mathrm{Zn}$ may be related to higher adsorption of this element by $\mathrm{Fe}$ and $\mathrm{Ti}$ oxides. This is a result of the dominant role of $\mathrm{pH}$ in the dynamic of PTEs in the soil. At a $\mathrm{pH}$ above 5.9, the metal is stable in the soil solid phase because of the deprotonation of the hydroxyl at the edges of the mineral which promotes an increase in net negatively charged soil, which favors adsorption of metals (MAMIDY-PAJANY et al., 2014). The pH varied between 4.16 and 7.08, with higher levels in the sections most affected by prospecting activity (P1, P2, P3, P4, and P5) and the higher total PTE levels.

$\mathrm{Pb}, \mathrm{Cu}$, and $\mathrm{Zn}$ contents represent a risk to human health, considering the recommendations of the Agency for Toxic Substances and Disease Registry (ATSDR) (2014) of the United States. These metals occupy, respectively, the $2 \mathrm{nd}$, 75th, and 118th positions on the list of toxic substances (ATSDR, 2007), indicating that this field deserves governmental intervention to prevent further damage to the environment and local population health.

\section{CONCLUSIONS}

Total and available contents of $\mathrm{Cu}, \mathrm{Mo}, \mathrm{Pb}$, and $\mathrm{Zn}$ in the $\mathrm{Au}$ mining area of Serra Pelada are high, presenting a risk both to the ecosystem and local population health.

PCA was adequate in identifying the association of $\mathrm{Zn}$ with $\mathrm{Fe}$ oxides and $\mathrm{Ti}$ and $\mathrm{Pb}$ with Mn oxides.

The artisanal $\mathrm{Au}$ mining activities in Serra Pelada have negatively impacted the environment via the enrichment of and contamination by $\mathrm{Cu}, \mathrm{Mo}$, $\mathrm{Pb}$ and $\mathrm{Zn}$, which requires monitoring of these areas and policy control to avoid pollutant extraction and dispersion via crop cultivation activity in the surrounding mine area. 
RESUMO: O empilhamento superficial de volume expressivo de rejeito e estéril, com alto teor de elementos potencialmente tóxicos causou danos ambientais até hoje não mensurados. Neste contexto, constituiu-se objetivo deste trabalho, avaliar os teores totais e disponíveis de $\mathrm{Cu}, \mathrm{Mo}, \mathrm{Pb}$ e $\mathrm{Zn}$ e determinar índices indicadores de contaminação em solos na área de exploração artesanal de Au em Serra Pelada -Amazônia, Brasil. Para tanto, foram coletados seis pontos amostrais no entorno do lago formado a partir da cava e um ponto em área de mata sem influência do garimpo. Os teores totais e disponíveis dos metais foram extraídos com água régia e solução $0,5 \mathrm{~mol} \mathrm{~L}^{-1} \mathrm{HCl}$ respectivamente, seguidos das determinações através da espectrometria de emissão ótica com plasma de argônio acoplado indutivamente (ICP-OES). Todos os PTEs apresentaram teores totais acima dos valores de referência de qualidade para solos do estado do Pará. Os teores disponíveis de $\mathrm{Cu}, \mathrm{Pb}$ e $\mathrm{Zn}$ foram superiores aos observados em solos de área de floresta do estado do Pará. Os teores de $\mathrm{Cu}$ total estão acima do valor de prevenção definido pelo Conselho Nacional de Meio Ambiente. Em média houve enriquecimento de $\mathrm{Mo}(41,0)>\mathrm{Cu}(3,5)>\mathrm{Pb}(1,4)$, o que indica que as áreas foram contaminadas por PTEs a partir das atividades antrópicas.

PALAVRAS-CHAVE: Serra Pelada. Mineração de ouro. Solos. Metais pesados. Contaminação. Mineração artisanal. Garimpo.

\section{REFERENCES}

AGENCY FOR TOXIC SUBSTANCES AND DISEASE REGISTRY-ATSDR. 2014. Priority list of hazardous substances. Available online at: http://www.atsdr.cdc.gov/spl/ (verified on October 14, 2016).

ALMADA, M. C. O.; VILLAS, R. N. The Bahia deposit: a possible example sulfide deposit vulcanogênico type Besshi Archean in Carajás. Revista Brasileira de Geociências, São Paulo, v. 29, n. 4, p. 579-592, dec. 1999.

ANJU, M.; BANERJEE, D. K. 2011. Multivariate statistical analysis of heavy metals in soils of a Pb-Zn mining area, India. Environmental monitoring and assessment, Heidelberg, v. 184, n. 7, p. 4191-4206, jul. 2011.

BARROS, Y. J.; MELO, V. F.; KUMER, L.; SOUZA, L. C. P.; AZEVEDO, J. C. Indicadores físicos e químicos de qualidade de solos de área de mineração e metalurgia de chumbo. Semina: Ciência Agrária, Londrina, v. 32, n. 4, p. 1385-404, out. 2011. https://doi.org/10.5433/1679-0359.2011v32n4p1385

BHUIYAN, M. A. H.; PARVEZ, L.; ISLAM, M. A.; DAMPARE, S. B.; SUZUKI, S. Heavy metal pollution of coal mine-affected agricultural soils in the northern part of a Bangladesh. Journal Hazardous Materials, Amsterdam, v. 173, n. 1-3, p. 384-392, jan. 2010. https://doi.org/10.1016/j.jhazmat.2009.08.085

BIRANI, S.; FERNANDES, A. R.; BRAZ, A. M. S.; PEDROSO, A. J. S.; ALLEONI, L. R. F. Available contents of potentially toxic elements in soils from the Eastern Amazon. Chemie der Erde, Amsterdam, v. 75, n. 1, p. 143-151, mar. 2015. https://doi.org/10.1016/j.chemer.2015.01.001

CESAR, R.; EGLER, S.; POLIANOV, H.; CASTILHOS, Z.; RODRIGUES, A. P. Mercury, copper and zinc contamination in soils and fluvial sediments from an abandoned gold mining area in southern Minas Gerais State Brazil. Environment Earth Science, Heidelberg, v. 64, v. 9, p. 211-222, may. 2015.

CONSELHO NACIONAL DE MEIO AMBIENTE - CONAMA. BRAZIL. Resolução no 420. 2009. Dispõe sobre critérios e valores orientadores de qualidade do solo quanto à presença de substâncias químicas e estabelece diretrizes para o gerenciamento ambiental de áreas contaminadas por essas substâncias em decorrência de atividades antrópicas. [Acessado em 16 janeiro 2012]. Disponível em: http://www.mma.gov.br/port/conama/legiabre.cfm?codlegi=620.

Embrapa. 2011. Manual de análises químicas de solos, plantas e fertilizantes. $2^{a}$.ed. Centro Nacional de Pesquisa de Solos, Brasília, DF. 
FAZ, A.; ZORNOZA, R.; MUÑOZ, A.; ACOSTA, J. A. Metals and metalloids in primary gold minning districts of Weatern Bolivia: antropogenic and natural sources. Environmental Earth Science, Heidelberg, v. 71, n. 12, p. 5027-5036, jun. 2014. https://doi.org/10.1007/s12665-013-2894-x

FERNANDES, A.R.; SANTOS, E. S.; BRAZ, A.M.S.; BIRANI, S.M.; ALLEONI, L.R.F. Quality reference values and background concentrations of potentially toxic elements in soils from the Eastern Amazon, Brazil. Journal of Geochemical Exploration, Amsterdam, v. 190, 453-463, jul. 2018. https://doi.org/10.1016/j.gexplo.2018.04.012

GETANEH, W.; ALEMAYEHU, T. 2006. Metal contamination of the environment by placer and primary gold mining in the Adola region of southern Ethiopia. Environmental Geology, Heidelberg, v. 50, n. 3, p. 339-352, jun. 2006. https://doi.org/10.1007/s00254-006-0213-5

KABATA-PENDIAS A. 2011. Trace Elements in Soils and Plants. 4. Ed. Boca Ranton: CRC Press, 2011. 534 p.

KESHAVARZI, B.; MOORE, F.; RASTMANESH, F.; KERMANI, M. Arsenic in the Muteh gold mining district, Isfahan, Iran. Environmental Earth Science, Heidelberg, v. 67, n. 4, p. 959-970, oct. 2012. https://doi.org/10.1007/s12665-012-1532-3

KRISHNA, A. K.; MOHAN, K. R.; MURTHY, N. N.; PERIASANY, V.; BIPINKUMAR, G.; MANOHAR, K.; RAO, S. S. 013. Assessment of heavy metal contamination in soils around chromite mining areas, Nuggihalli, Karnataka, India. Environmental Earth Science, Heidelberg, v. 70, n. 2, p. 699-708, sep. 2013. https://doi.org/10.1007/s12665-012-2153-6

LEE, C. Y.; KIM, T.; KOMARNENI, S.; HAN, S. K.; CHO, Y. Sorption characteristics of lead cations on microporous organo-birnessite. Applied Clay Science, Amsterdan, v. 83-84, p. 263-269, oct. 2013.

MAMINDY-PAJANY, M.; SAYEN, S.; MOSSELMANS, J. F. W.; GUILLON, E. Copper, Nickel and Zinc Speciation in a Biosolid-Amended Soil: $\mathrm{pH}$ Adsorption Edge, $\mu$ XRF and $\mu$ XANES Investigations.

Environmental Science Technology, Washington, v. 48, n. 13, p. 7237-7244, jun. 2014.

https://doi.org/10.1021/es5005522

MCGRATH, S. P.; CUNLIFFE, C. H. A simplified method for the extraction of metals $\mathrm{Fe}, \mathrm{Zn}, \mathrm{Cu}, \mathrm{Ni}, \mathrm{Cd}, \mathrm{Pb}$, Cr, Co and Mn from soils and sewage sludges. Journal Science Food Agriculture, Londres, v. 36, n. 9, p. 784-798, sep. 1985. https://doi.org/10.1002/jsfa.2740360906

MORONI, M.; VICENTE, A. V.; FERRARIO, G. A. The Serra pelada Au-PGE deposit, Serra dos Carajás (Pará State, Brazil): geological and geochemical indicators for a composite mineralising process. Mineralium Deposita, Heidelberg, v. 36, n. 8, p. 768-785, dec. 2001. https://doi.org/10.1007/s001260100201

MULLER, G. 1969. Index of geoaccumulation in sediments of the Rhine River. Geojournal, Heidelberg, v. 2, n. 3, p. 108-118.

NAGAJYOTI, P. C.; LEE, K. D.; SREEKANTH, T. V. M. Heavy metals, occurrence and toxicity for plants: a review. Environmental Chemistry Letters, Heidelberg, v. 8, n. 3, p. 199-216, sep. 2010. https://doi.org/10.1007/s10311-010-0297-8

ODUMO, O. B.; MUSTAPHA, A. O.; PATEL, J. P.; ANGEYO, H. K. Multielemental analysis of Migori (Southwest, Kenya) artisanal gold mine ores and sediments by EDX-ray fluorescence techinique: implications of occupational exposure and environmental impact. Bulletin Environmental Contamination and

Toxicology, Heidelberg, v. 86, n. 5, p. 484-489, may. 2011. 
PASSARRIELLO, B.; GIULANO, V.; QUARESIMA, S.; BARBARO, M.; CAROLI, S.; FORTE, G. Evaluation of the environmental contamination at an abandoned mining site. Microchemical Journal, Amsterdam, v. 73, n. 1-2, p. 245-250, oct. 2002. https://doi.org/10.1016/S0026-265X(02)00069-3

RASHED, M. N. Monitoring of contaminated toxic and heavy metals, from mine tailings trough age accumulation, in soil and some wild plants at Southest Egypt. Journal Hazardous Materials, Amsterdam, v. 178, n. 1-3, p. 738-46, jun. 2010.

RIEUWERTS, J. S. The mobility and bioavailability of trace metals in tropical soils: A review. Chemical Speciation and Bioavailability, Abingdon, v. 19, n. 2 p. 75-85, mar. 2007.

https://doi.org/10.3184/095422907X211918

ROULET, M.; LUCCOTE, M.; SAINT-AUBIN, S.; TRAN, S.; RHÉAULT, I.; FARELLA, N.; SILVA, E. J.; DEZENCOURT, J.; PASSOS, C. J. S.; SOARES, G. S.; GUIMARÃES, J. R. D.; MERGLER, D.; AMORIM, M. The Geochemistry of mercury in central Amazonian soils on the Alter-do-Chão formation of the lower Tapajós River Valley, Pará, Brazil. Science Total Environmental, Amsterdam, v. 223, n. 1, p. 1-24, nov. 1998. https://doi.org/10.1016/S0048-9697(98)00265-4

RUSSELL, J. B. Química Geral. 2. ed. São Paulo: Makron Books, 2008. 946 p.

SAKAN, S. J.; DORDEVIC, D. S.; MANOJLOVIC, D. D.; PEDRAG, P. S. Assesment of heavy metal pollutants accumulation in the Tisza river sediments. Journal Environment Management, Amsterdam, v. 90, n. 11, p. 382-390, aug. 2009.

SILVA, D.S.; LUCCOTE, M.; DAVIDSON, R. Influence of ecological factors and land use on Mercury levels in fish in the Tapajós River basin, Amazon. Environmental Research, Amsterdam, v.109, n.4, p. 432-446, may. 2009.

SOUZA, E. S.; FERNANDES, A. R.; SABINO, L. L. L.; BRAZ, A. M. S.; ALLEONI, L. R. F. Potentially toxic elements (PTEs) in soils from the surroundings of the Trans-Amazonian Highway, Brazil.

Environmental Monitoring Assessment, Heidelberg, v. 187, n. 1, p. 4074-4094, nov. 2015. https://doi.org/10.1007/s10661-014-4074-1

SPIEGEL, S. J.; VEIGA, M. M. International guidelines on mercury management in small-scale gold mining. Journal Cleaner Production, Amsterdam, v. 18, n. 4, p. 375-385, mar. 2010.

https://doi.org/10.1016/j.jclepro.2009.10.020

TALlARICO, F. H. B., COIMBRA, C. R., COSTA, C. H. C. The Serra Pelada sediment-hosted Au-(Pd-Pt) mineralization Carajás Province. Brazilian Journal Geology, São Paulo, v. 30, n. 2, p. 226-239, jun. 2000.

TEDESCO, M. J.; GIANELLO, C.; BISSANI, C.; BOHNEN, H.; VOLKWEISS, S. J. Análise de solo, plantas e outros materiais. 2.ed. Porto Alegre: UFRGS, Departamento de Solos, 1995. 118p. (Boletim Técnico, 5).

VEIGA, M. M.; HINTON, J. J. Abandoned artisanal gold mines in the Brazilian Amazon: A legacy of mercury pollution. Natural Resources Forum, Londres, v. 26, n. 1, p. 15-26, feb. 2002. https://doi.org/10.1111/14778947.00003

VEIGA, M. M..; MAXSON, P. A.; HYLANDER, L. D. Origin and consumption of mercury in small-scale gold mining. Journal Cleaner Production, Amsterdam, v. 14, n. 3-4, p. 436-447, aug. 2006.

https://doi.org/10.1016/j.jclepro.2004.08.010

WANG, S.; GAO, B.; LI, Y.; MOSA, A.; ZIMMERMAN, A.R.; MA, L.Q.; HARRIS, W.G.; MIGLIACCIO, K.W. Manganese oxide-modified biochars: Preparation, characterization, and sorption of arsenate and lead.

Bioresource Technology, Amsterdam, v. 18, p. 3-17, apr. 2015. https://doi.org/10.1016/j.biortech.2015.01.044

WU, Y.; XU, Y; ZHANG, J.; HU, S.; LIU, K. Heavy metals pollution and the identification of their sources in soil over Xiaoqinling gold-mining region, Shaanxi, China. Environmental Earth Sciences, Heidelberg, n. 64, p. 1585-1592, 2011. 